\title{
Pengaruh Dimensi Kepribadian Big Five terhadap Pola Pikir Kewirausahaan Mahasiswa
}

\author{
Farhanaz Safira ${ }^{* 1}$, Siti Zahreni ${ }^{2}$ \\ 1,2 Program Studi Psikologi, Fakultas Psikologi, Universitas Sumatera Utara, \\ Indonesia. \\ *)Corresponding author, Đe-mail: frhnzsfra98@gmail.com
}

\begin{tabular}{ccc}
\hline Received: & Accepted: & Published: \\
29 July 2021 & 20 October 2021 & 31 December 2021 \\
\hline
\end{tabular}

\begin{abstract}
This study was conducted to determine the effect of the big five personality dimensions on the entrepreneurial mind-set. The subjects in the study were 100 university students ( $38 \%$ male, $62 \%$ female) with age range of 18 25 Year $(M=20, S D=1.528)$. Sampling was done by using proportioned random sampling method. The instrument used is the big five personality dimension scale and the entrepreneurial mind-set scale. The data examined by multiple regression analysis test. The results of data analysis indicated that there was an influence of the big five personality dimensions on the entrepreneurial mind-set $(R 2=.58, F(5.94)=25.98, p=.000)$. The dimensions of extraversion, openness to experience and conscientiousness have a significant effect on the entrepreneurial mind-set. Future research is expected to be carried out on different subjects to see the consistency of research results.
\end{abstract}

Keywords: Mindset, Entrepreneurship, Personality, Big Five, Student

\begin{abstract}
Abstrak
Penelitian ini dilakukan untuk mengetahui pengaruh dimensi kepribadian big five terhadap pola pikir kewirausahan. Subjek dalam penelitian adalah 100 mahasiswa (38 \% laki-laki, 62\% Perempuan) dengan rentang usia 18-25 Tahun $(M=20, S D=1.528)$. Pengambilan sampel dilakukan dengan menggunakan metode proportioned random sampling. Alat ukur yang digunakan adalah skala dimensi kepribadian big five dan skala pola pikir kewirausahaan. Data diolah dengan uji analisa regresi berganda. Hasil analisa data menunjukkan terdapat pengaruh dimensi kepribadian big five terhadap pola pikir kewirausahaan $\left(R^{2}=.58, F(5,94)=25.98, p=\right.$ .000). Dimensi extraversion, opennes to experience dan conscientiousness berpengaruh signifikan terhadap pola pikir kewirausahaan. Hasil kajian ini bermanfaat bagi konselor di perguruan tinggi dalam merumuskan program kewirausahaan bagi mahasiswa.
\end{abstract}

Kata Kunci: Pola Pikir, Kewirausahaan, Kepribadian, Big Five, Mahasiswa

\section{PENDAHULUAN}

Tingginya angka pengangguran merupakan fenomena empiris yang terjadi di Indonesia (Wijaya, 2008). Namun, pada awal tahun 2020, terjadi penyebaran virus
Covid-19 yang membawa risiko sangat buruk bagi perekonomian Indonesia (Nasution, Erlina, \& Muda, 2020). Berdasarkan data Badan Pusat Statistik (BPS) mencatat jumlah pengangguran di 
Indonesia pada Agustus 2020 mencapai 9,77 juta orang yang mana jumlah pengangguran tersebut naik 2,67 juta orang dibandingkan dengan periode yang sama tahun lalu. Data ini mengkonfirmasi bahwa penambahan pengangguran turut dipengaruhi pandemi Covid-19 (Kurniati, 2020). Dengan demikian, kondisi ini membuat tingkat pengangguran menjadi masalah mendasar dalam ketenagakerjaan di Indonesia.

Salah satu alasan tingginya angka pengangguran dikarenakan terbatasnya lapangan pekerjaan. Rasio lapangan pekerjaan dan jumlah penduduk yang tidak sesuai menyebabkan persaingan yang ketat dalam mencari pekerjaan (Indayani \& Hartono, 2020). Terlebih lagi Wijaya (2008) menyatakan penduduk Indonesia cendurung memilih pekerjaan sebagai pegawai negeri ataupun swasta dikarenakan adanya kecendurungan menghindari risiko gagal dan pendapatan yang tidak tetap. Sehingga menyebabkan angka pengangguran di Indonesia terus meningkat.

Pesatnya jumlah pengangguran di Indonesia ini terjadi pada kalangan tidak berpendidikan maupun yang berpendidikan tinggi. Salah satu permasalahan yang dihadapi kalangan berpendidikan tinggi adalah mahasiswa. Hal ini terjadi karena adanya keterbatasan kesempatan kerja. Pada umumnya para mahasiswa hanya terpaku pada keinginan untuk mencari pekerjaan pada perusahaanperusahaan besar maupun instansi pemerintah guna menjamin masa depan mereka (Ustha, 2018). Hal ini tercermin dari tingkat pengangguran terbuka (TPT)

lulusan universitas dengan rentang pendidikan S1 hingga S3 yang mencapai 737.000. Berdasarkan hasil pendataan yang dilakukan BPS, per Agustus 2019, jumlah pengangguran lulusan universitas mencapai 5,67 persen dari total angkatan kerja sekitar 13 juta orang. Meski persentasenya turun dibandingkan Agustus 2018 yang 5,89 persen, angkanya di atas rata-rata pengangguran nasional yang sebesar 5,28 persen (Rahayu, 2019). Meningkatnya jumlah pengangguran lulusan terdidik terjadi karena bertambahnya angkatan kerja yang tidak terserap sepenuhnya oleh lapangan pekerjaan.

Adapun salah satu cara untuk menurunkan angka pengangguran adalah dengan berwirausaha. Kegiatan berwirausaha akan memiliki dampak yang positif untuk meningkatkan kesejahteraan pada masyarakat. Kewirausahaan merupakan kemampuan yang kreatif dan inovatif, jeli dalam melihat peluang dan berpikiran terbuka untuk setiap masukan perubahan yang positif (Saragih, 2017). Selanjutnya, Sumardi (2007) menjelaskan bahwa pengusaha atau wirausahawan (entrepreneur) merupakan seorang yang menciptakan sebuah usaha atau bisnis yang diharapkan dengan risiko dan ketidakpastian untuk memperoleh keuntungan dan mengembangkan bisnis dengan cara membuka kesempatan. Dengan begitu, seorang wirausahawan memiliki kemampuan dalam hal menciptakan lapangan pekerjaan serta memiliki sikap mandiri dan mampu memanfaatkan setiap peluang yang ada 
dengan mengoptimalkan potensi dalam membuat keputusan (Aprilianty, 2013).

Keputusan seseorang untuk berwirausaha dipengaruhi oleh beberapa faktor penting, salah satunya adalah pola pikir kewirausahaan (Suaidy \& Lewenussa, 2019). McGrath dan MacMillan (2000) mendefinisikan pola pikir kewirausahaan sebagai kemampuan dengan cepat merasakan, bertindak, dan memobilisasi bahkan dalam kondisi dengan ketidakpastian serta mau belajar dari dampak yang dihasilkan oleh risiko yang dihadapi. McGrath dan MacMillan (2000) juga mengajukan beberapa karakteristik pada individu yang memiliki pola pikir kewirausahan seperti, memiliki pemikiran sederhana, berorientasi pada tindakan, penuh semangat mencari peluang yang baru, memiliki disiplin tinggi, fokus pada eksekusi, serta pandai bersosialisasi dan membangun jaringan.

Individu yang memiliki pola pikir kewirausahaan diprediksi dapat meningkatkan keberhasilan dalam berwirausaha dan mampu mengatasi risiko yang dihadapi serta mampu melihat peluang dalam keadaan yang tidak pasti (Naumann, 2017). Memiliki pola pikir kewirausahaan dapat mengubah cara berpikir dari mencari kerja (job seeker) menjadi pencipta lapangan pekerjaan (job creator) serta dapat menjadi pengusaha yang tangguh dan sukses dalam menjalankan usahanya (Hutagalung \& Hutagulung, 2018).

Dalam ruang lingkup
berwirausaha, pola pikir ditentukan oleh faktor eksternal dan internal. Fakor internal meliputi kepribadian, persepsi, motivasi dan pembelajaran (Larviatmo \& Ratnawati, 2018). Hal ini juga disampaikan oleh Karabulut (2016) yang menguraikan bahwa sifat kepribadian memiliki efek positif pada kewirausahaan. Evaluasi mengenai kepribadian seseorang memiliki pengaruh pada keberhasilan dalam melakukan kewirausahaan (Larviatmo \& Ratnawati, 2018). Adapun Suryana (2006) mengatakan bahwa keberhasilan atau kegagalan wirausaha sangat dipengaruhi oleh sifat dan kepribadian individu. Sehingga disimpulkan bahwa pola pikir wirausaha dipengaruhi oleh kepribadian seseorang yang kemudian menentukan berhasil atau tidaknya seseorang dalam melakukan usahanya.

Menurut Dorland

kepribadian merupakan pola khas seseorang dalam berpikir, merasakan dan berperilaku yang relatif stabil dan dapat diperkirakan. Kepribadian tersebut kadang kala membedakannya dari kebanyakan orang (Nugrahaningsih \& Muslim, 2016). Para psikolog berpendapat bahwa kepribadian berhubungan dengan jenis karir yang dipilih seseorang dan bagaimana mereka berfungsi dalam pekerjaan ini (Pervin, Cervone, \& John, 2010). Banyak pendekatan yang dilakukan untuk mengkaji kepribadian. Salah satu diantaranya adalah dengan menggunakan pendekatan teori kepribadian big five (big five personality) (Sarinah, 2017). Menurut Goldberg dalam John \& Soto, 2007 merupakan salah satu pengembang tipe kepribadian, big five personality dibangun dengan meneliti dasar-dasar kepribadian dan menganalisis perkataan yang kerap digunakan dalam kehidupan sehari-hari 
untuk menggambarkan tipe kepribadian seseorang. Goldberg menemukan adanya lima dimensi utama yaitu extraversion, openness to experience, neuroticism, conscientiousness, dan agreeableness (John \& Soto, 2007).

Berdasarkan pemaparan diatas, penelitian ini bertujuan untuk meneliti pengaruh dimensi kepribadian big five terhadap pola pikir kewirausahaan. Selain itu penelitian terkait pola pikir kewirausahaan dan kepribadian masih belum banyak diteliti di Indonesia. Sehingga, penelitian ini menjadi sesuatu yang penting untuk diteliti. Terdapat beberapa hipotesis dalam penelitian ini yaitu, pertama terdapat pengaruh dimensi kepribadian big five terhadap pola pikir kewirausahaan. Kedua, terdapat pengaruh dimensi openness to experience terhadap pola pikir kewirausahaan. Ketiga, terdapat pengaruh dimensi conscientiousness terhadap pola pikir kewirausahaan. Keempat, terdapat pengaruh dimensi extraversion terhadap pola pikir kewirausahaan. Kelima, terdapat pengaruh dimensi agreeableness terhadap pola pikir kewirausahaan dan yang terakhir terdapat pengaruh dimensi neuroticism terhadap pola pikir kewirausahaan.

\section{METODE}

Penelitian ini menggunakan pendekatan kuantitatif non-eksperimen yaitu pendekatan kausalitas dengan teknik analisis regresi linier berganda.

\section{Partisipan}

Partisipan pada penelitian ini adalah 100 (Laki-laki: 38\%, Perempuan: 62\%) Mahasiswa aktif S1 Fakultas Psikologi
Universitas Sumatera Utara angkatan 2015 s/d 2020 dengan rentang usia 18-25 tahun $(M: 20, S D: 1,589)$ yang dipilih dengan menggunakan teknik proportioned random sampling. Semua partisipan terlebih dahulu mengisi informed consent sebelum berpartisipasi, untuk memastikan bahwa dalam pengisiannya secara sukarela dan dalam keadaan sadar.

\section{Alat Ukur}

\section{Skala Pola Pikir Kewirausahaan}

Skala Pola Pikir Kewirausahaan disusun menggunakan dimensi-dimensi yang dikemukakan oleh McGrath \& MacMillan (2000) yaitu, orientasi pada aksi, berpikir sederhana, berkreasi mencari alternatif peluang baru, memiliki integritas dalam mengejar peluang, mengambil peluang yang terbaik, fokus pada eksekusi dan memfokuskan energi setiap orang di wilayah mereka. Aitem-aitem dalam skala Pola Pikir Kewirausahaan merupakan pernyataan yang terdiri dari lima pilihan jawaban, yaitu Sangat Setuju $=5$, Setuju $=4$, Netral $=3$, Tidak Setuju $=2$ dan Sangat Tidak Setuju $=1$. Sedangkan bobot penilaian untuk pertanyaan unfavorable yaitu Sangat Setuju $=1$, Setuju $=2$, Netral $=$ 3, Tidak Setuju $=4$, dan Sangat Tidak Setuju = 5). Berdasarkan uji Cronbach's alpha coefficient, didapatkan reliabilitas skala Pola Pikir Kewirausahaan sebesar 0.923 sehingga dapat disimpulkan bahwa skala Pola Pikir Kewirausahaan reliabel untuk digunakan.

\section{Skala Dimensi Kepribadian Big Five}

Skala dimensi kepribadian big five disusun menggunakan dimensi-dimensi yang dikemukakan oleh Goldberg dalam (John \& Soto, 2007) yaitu, extraversion, 
agreaableness, neuroticism, opennes to masing dimensi kepribadian big five yaitu: experience dan conscientiousness. Aitem- 0,875 untuk dimensi extraversion, 0,723 aitem dalam skala dimensi kepribadian big untuk dimensi agreeableness, 0,907 untuk five merupakan pernyataan yang terdiri dimensi neuroticism, 0,809 untuk dimensi dari lima pilihan jawaban, Sangat Setuju $=$ openness to experience, 0,764 untuk dimensi 5 , Setuju $=4$, Netral $=3$, Tidak Setuju $=2$ dan Sangat Tidak Setuju $=1$. Sedangkan bobot penilaian untuk pertanyaan conscientiousness. Dapat disimpulkan bahwa skala Dimensi Kepribadian Big Five reliabel untuk digunakan. unfavorable yaitu Sangat Setuju $=1$, Setuju $=$ 2, Netral $=3$, Tidak Setuju $=4$, dan Sangat Tidak Setuju $=5$ ). Skala pada penelitian ini menggunakan Big Five Inventory Scale yang diadaptasi secara bahasa dan budaya oleh Neila Ramdhani dari Universitas Gadjah Mada Versi Bahasa Indonesia yang terstandarisasi (Ramdhani, 2012). Berdasarkan uji Cronbach's alpha coefficient didapatkan reliabilitas skala untuk masing- atribut yang diukur (Azwar, 2012).

Tabel 1. Distribusi partisipan pada variabel dimensi kepribadian big five dan pola pikir kewirausahaan

\begin{tabular}{ccccc}
\hline Variabel & Rentang Nilai & Kategori & Jumlah & Persentase \\
\hline \multirow{2}{*}{ Extraversion } & $\mathrm{X}<16,33$ & Rendah & 20 & $20 \%$ \\
& $16,34 \leq \mathrm{X}<25,65$ & Sedang & 44 & $44 \%$ \\
& 25,66 & Tinggi & 36 & $36 \%$ \\
& Total & & $\mathbf{1 0 0}$ & $\mathbf{1 0 0 \%}$ \\
& $\mathrm{X}<18,66$ & Rendah & 9 & $9 \%$ \\
Agreeablenes & $18,67 \leq \mathrm{X}<29,32$ & Sedang & 67 & $67 \%$ \\
s & 29,33 & Tinggi & 24 & $24 \%$ \\
& Total & & $\mathbf{1 0 0}$ & $\mathbf{1 0 0 \%}$ \\
& $\mathrm{X}<18,66$ & Rendah & 9 & $9 \%$ \\
Agreeablenes & $18,67 \leq \mathrm{X}<29,32$ & Sedang & 67 & $67 \%$ \\
& 29,33 & Tinggi & 24 & $24 \%$ \\
& Total & & $\mathbf{1 0 0}$ & $\mathbf{1 0 0 \%}$ \\
& $\mathrm{X}<16,33$ & Rendah & 43 & $43 \%$ \\
Neuroticism & $16,34 \leq \mathrm{X}<25,65$ & Sedang & 31 & $31 \%$ \\
& 25,66 & Tinggi & 26 & $26 \%$ \\
& Total & & $\mathbf{1 0 0}$ & $\mathbf{1 0 0 \%}$ \\
& $\mathrm{X}<18,66$ & Rendah & 1 & $1 \%$ \\
Opennes to & $18,67 \leq \mathrm{X}<29,32$ & Sedang & 54 & $54 \%$ \\
Experience & 29,33 & Tinggi & 45 & $45 \%$ \\
& Total & & $\mathbf{1 0 0}$ & $\mathbf{1 0 0 \%}$ \\
\hline
\end{tabular}




\begin{tabular}{ccccc}
\hline \multirow{2}{*}{ Conscientious } & $\mathrm{X}<18,66$ & Rendah & 11 & $11 \%$ \\
ness & $18,67 \leq \mathrm{X}<29,32$ & Sedang & 72 & $72 \%$ \\
& 29,33 & Tinggi & 17 & $17 \%$ \\
& Total & & $\mathbf{1 0 0}$ & $\mathbf{1 0 0 \%}$ \\
Pola pikir & $\mathrm{X}<69,5$ & Rendah & 1 & $1 \%$ \\
kewirausahaan & $70 \leq \mathrm{X}<109,5$ & Sedang & 56 & $56 \%$ \\
& 110 & Tinggi & 43 & $43 \%$ \\
& Total & & $\mathbf{1 0 0}$ & $\mathbf{1 0 0 \%}$ \\
\hline
\end{tabular}

Selanjutnya, berdasarkan hasil analisa data dimensi kepribadian big five terhadap pola ditemukan bahwa terdapat pengaruh pikir kewirausahaan.

Tabel 2. Hasil Uji Regresi Berganda

\begin{tabular}{cccccc}
\hline Model & $\mathrm{R}$ & $\mathrm{R}$ Square & $\beta$ & $\mathrm{t}$ & $\mathrm{p}$ \\
\hline Constant & - & - & 41.503 & 6.313 & .000 \\
Extraversion & .659 & .434 & .170 & .400 & .021 \\
Agreaableness & .691 & .478 & .026 & .072 & .616 \\
Neuroticism & .694 & .481 & .665 & 1.644 & .104 \\
Openness & .754 & .569 & 1.163 & 3.343 & .005 \\
Conscientiousness & .762 & .580 & .594 & 1.584 & .022 \\
\hline
\end{tabular}

Berdasarkan dari nilai koefisien 6.313, $p=0,000<0,05$ yang berarti nilai regresi didapatkan nilai $\beta$ sebesar $41.503 \mathrm{t}=$ signifikansi kurang dari 0,05. Maka dapat diartikan bahwa Ha diterima.

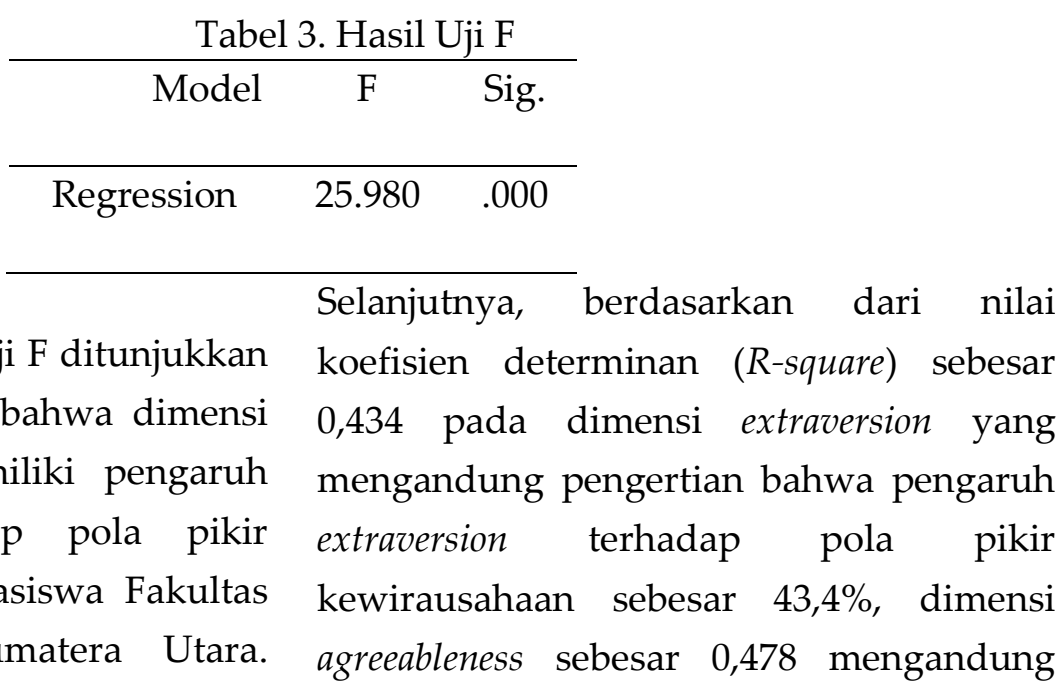


pengertian bahwa pengaruh agreeableness terhadap pola pikir kewirausahaan sebesar $47.8 \%$, dimensi neuroticism sebesar 0,481 bermakna bahwa pengaruh neuroticism terhadap pola pikir kewirausahaan sebesar $48,1 \%$, dimensi openness to experience sebesar 0,569 mengandung pengertian bahwa pengaruh openness to experience terhadap pola pikir kewirausahaan sebesar 56,9\%, dan dimensi conscientiousness sebesar 0,580 mengandung pengertian bahwa pengaruh conscientiousness terhadap pola pikir kewirausahaan sebesar 58,0\% pada mahasiswa Fakultas Psikologi Universitas Sumatera Utara. Sedangkan sisanya dipengaruhi oleh faktor-faktor yang tidak ada dalam penelitian ini.

\section{PEMBAHASAN}

HasiI penelitian menunjukkan adanya pengaruh dimensi kepribadian big five terhadap pola pikir kewirausahaan. Dari hasiI anaIisis penelitian ini menyatakan terdapat pengaruh positif pada dimensi extraversion terhadap pola pikir kewirausahaan. Hal ini sesuai dengan hipotesis awal penelitian yang mengatakan bahwa ada pengaruh dimensi extraversion terhadap pola pikir kewirausahaan. Hasil ini diperkuat dengan Antoncic, Kregar, Singh, \& Denoble (2015), yang menyatakan bahwa orang-orang yang memiliki skor rendah pada extraversion mungkin sangat kecil kemungkinannya untuk menjadi seorang wirausaha dibandingkan dengan orang yang memiliki skor tinggi pada extraversion. Hal ini sesuai dengan teori Goldberg dalam John \& Soto (2007)bahwa individu dengan kepribadian extrovert cenderung lebih sosial dan dapat menjain hubungan yang akan sangat penting untuk keberlangsungan hidup dan pertumbuhan bisnis.

Dimensi openness to experience berpengaruh terhadap pola pikir kewirausahaan. Hal ini sesuai dengan hipostesis awal penelitian yang mengatakan ada pengaruh dimensi openness to experience terhadap pola pikir kewirausahaan. Hasil penelitian ini diperkuat dengan yang ditemukan oleh Antoncic, Kregar, Singh, \& Denoble (2015)yang menemukan hubungan positif antara dimensi openness to experience dengan pola pikir kewirausahaan. Orangorang dengan kepribadian openness to experience dapat digambarkan sebagi orang yang kreatif, imajinatif, filosofis, intelektual, dan mungkin cenderung memiliki kemungkinan yang lebih besar untuk menjadi pengusaha daripada orang lain (Goldberg dalam John \& Soto, 2007).

Dimensi

conscientiousness berpengaruh terhadap pola pikir kewirausahaan. Hasil penelitian ini sesuai dengan hipotesis awal penelitian yang mengatakan bahwa ada pengaruh dimensi conscientiousness terhadap pola pikir kewirausahaan. Hal ini didukung oleh Goldberg dalam John \& Soto, 2007) menyatakan karakteristik positif yang dimiliki individu pada dimensi ini disiplin, pekerja keras serta memiliki tujuan. Sehingga hal ini berkaitan dengan karakteristik memiliki integritas dalam mengejar peluang, mengambil peluang yang terbaik, action oriented, serta berpikir sederhana (McGrath \& MacMillan, 2000). Individu dengan karakteristik pola pikir kewirausahaan ini memiliki integritas dan 
disiplin yang tinggi terhadap apa yang sedang dikerjakan.

Selanjutnya, terdapat dua dimensi terakhir yaitu dimensi neuroticism dan agreeableness. Pada dimensi neuroticism tidak berpengaruh terhadap pola pikir kewirausahaan. Hal ini tidak sesuai dengan hipostesis awal penelitian yang mengatakan bahwa terdapat pengaruh dimensi neuroticism terhadap pola pikir kewirausahaan. Dimensi neuroticism memiliki karakteristik yang mencakup perasaan-perasaan negatif, seperti kecemasan, kesedihan, mudah marah, dan tegang (Goldberg dalam John \& Soto, 2007). Hasil penelitian ini diperkuat dengan yang ditemukan oleh Hachana, Berraies, \& Ftiti (2018) yang menyatakan bahwa seorang dengan skor rendah pada neuroticism akan mengalami kesulitan untuk beradaptasi dengan lingkungan yang berubah dengan cepat.

Dimensi agreeableness tidak memiliki pengaruh terhadap pola pikir kewirausahaan. Hasil penelitian ini tidak sesuai dengan hipotesis awal penelitian yang menyebutkan bahwa ada pengaruh antara dimensi agreeableness terhadap pola pikir kewirausahaan. Individu dengan dimensi agreeableness yang dominan memiliki ciri-ciri perilaku seperti lebih patuh dengan individu lainnya dan menghindari konflik. Namun, hasil penelitian ini didukung oleh hasil penelitian Ismail, Mahmod, Khalid, Jusoff, Rahman, Kassim \& Zain (2009), yang menemukan bahwa agreeableness tidak memiliki korelasi dengan minat berwirausaha.
Meskipun demikian masih ada faktor lain yang mempengaruhi pola pikir kewirausahaan mahasiswa yang belum dikaji dalam penelitian ini. Hasil kajian ini dapat digunakan sebagai bahan acuan pada penelitian selanjutnya agar dapat memperkaya teori tentang psikologi kewirausahaan, khususnya mengenai faktor kepribadian yang mempengaruhi pola pikir kewirausahaan serta dapat digunakan dalam proses konseling karir, yang dapat membantu konselor dan konseli dalam proses menentukan karir dengan mempertimbangkan aspek kepribadian.

\section{SIMPULAN}

Berdasarkan hasil kajian disimpulkan bahwa dimensi kepribadian big five berpengaruh terhadap pola pikir kewirausahaan mahasiswa. Hal ini berarti bahwa dimensi kepribadian merupakan salah satu yang perlu menjadi perhatian bagi mahasiswa dalam menentukan minat kewirausahaan untuk sungguh-sungguh menentukan bidang berwirausaha sesuai dengan dimensi kepribadian yang dimiliki.

\section{UCAPAN TERIMA KASIH}

Terima kasih kepada partisipan Mahasiswa Program Studi S1 Psikologi Fakultas Psikologi Universitas Sumatera Utara yang telah berpartisipasi dan bersedia menjadi responden dalam penelitian ini.

\section{DAFTAR PUSTAKA}

Antoncic, B., Kregar, T. B., Singh, G., \& Denoble, A. F. (2015). The big five personality-entrepreneurship 
relationship: Evidence from Slovenia. Journal of Small Business Management, 53(3),

819-841.

https://doi.org/10.1111/jsbm.12089

Aprilianty, E. (2013). Pengaruh kepribadian wirausaha, pengetahuan kewirausahaan, dan lingkungan terhadap minat berwirausaha siswa SMK. Jurnal Pendidikan Vokasi, 2(3), 311-324.

https://doi.org/10.21831/jpv.v2i3.1039

Azwar, S. (2012). Reliabilitas dan validitas (Empat ed). Yogyakarta, Indonesia: Pustaka Pelajar.

Dorland, W. A. N. (2002). Kamus kedokteran Dorland. Jakarta: Penerbit Buku Kedokteran EGC.

Hachana, R., Berraies, S., \& Ftiti, Z. (2018). Identifying personality traits associated with entrepreneurial success: does gender matter? Journal of Innovation Economics \& Management, (3), 169.

https://doi.org/10.3917/jie.027.0169

Hutagalung, B., \& Hutagulung, A. Q. (2018). Pengaruh adversity quotient terhadap keberhasilan usaha pusat industri kecil medan denai. Jurnal Pendidikan Kewirausahaan Indonesia, 1(1), 60-69.

Indayani, S., \& Hartono, B. (2020). Analisis pengangguran dan pertumbuhan ekonomi sebagai akibat pandemi Covid-19. Jurnal Perspektif, 18(2), 201208.

Ismail, M., Khalid, S. A., Othman, M., Jusoff, H. K., Rahman, N. A., Kassim, K. M., \& Zain, R. S. (2009). Entrepreneurial intention among Malaysian undergraduates.
International Journal of Business and Management, $4(10)$. https://doi.org/10.5539/ijbm.v4n10p54 John, O. P., \& Soto, C. J. (2007). The importance of being valid: Reliability and the process of construct validation. In Handbook of research methods in personality psychology (In R. W. R). New York, NY: Cambridge University Press.

Karabulut, ahu T. (2016). Personality traits on entrepreneurial intention. Procedia Social and Behavioral Sciences, 229, 12 21.

https://doi.org/10.1016/j.sbspro.2016.0 7.109

Kurniati, D. (2020). Duh , jumlah pengangguran bertambah ! Ini data terbaru BPS. Retrieved December 12, 2020, from DDTC News website: https://news.ddtc.co.id/duh-jumlahpengangguran-bertambah-ini-dataterbaru-bps-25295? page_y $=0$

Larviatmo, M. H. D., \& Ratnawati, I. (2018). Pengaruh sifat kepribadian terhadap intensi menjadi wirausaha dengan efikasi diri sebagai variabel intervening (Studi pada mahasiswa Fakultas Ekonomika dan Bisnis Universitas Diponegoro Semarang). Jurnal Studi Manajemen Organisasi, 15, 51-65.

McGrath, R. G., \& MacMillan, I. C. (2000). The entrepreneurial mindset: Strategies for continuously creating opportunity in an age of uncertainty. In The entrepreneurial mindset. Boston: Harvard Business School Press. https://doi.org/10.2307/259188

Nasution, D. A. D., Erlina, \& Muda, I. 106 
(2020). Dampak pandemi Covid-19 terhadap perekonomian Indonesia. Jurnal Benefita, 5(2), 212-224.

Naumann, C. (2017). Entrepreneurial mindset : A synthetic literature review. Entrepreneurial Business and Economics Review, 5(3), 149-172.

Nugrahaningsih, H., \& Muslim, R. (2016). Pengaruh kepribadian, pengetahuan dan motivasi terhadap minat berwirausaha dengan perencanaan strategis sebagai variabel moderating pada Mahasiswa Fakultas Ekonomi di Universitas 17 Agustus 1945 Jakarta. Jurnal Online Internasional \& Nasional, 3(2), 1-20.

Pervin, L. A., Cervone, D., \& John, O. P. (2010). Psikologi kepribadian teori dan penelitian ed.9. In Psikologi Kepribadian Teori dan Penelitian edisi kesembilan. Jakarta:Kencana.

Rahayu, I. R. S. (2019). Agustus 2019 , Pengangguran lulusan universitas 737.000 orang.

Ramdhani, N. (2012). Adaptasi bahasa dan budaya inventori big five. Jurnal Psikologi, 39(2), 189-207. https://doi.org/10.1016/S01434004(97)90091-6

Saragih, R. (2017). Membangun usaha kreatif, inovatif dan bermanfaat melalui penerapan kewirausahaan sosial. Jurnal Kewirausahaan, 3(2), 2634.

Sarinah. (2017). Minat berwirausaha ditinjau dari kepribadian Extraversion pada mahasiswa Fakultas Ekonomi Universitas Dharmawangsa Medan. Jurnal Diversita, 3(1), 32-39.

Suaidy, H., \& Lewenussa, R. (2019).
Pengaruh pola pikir (Mindset) kewirausahaan terhadap motivasi dan keterampilan wirausaha mahasiswa Program Studi Manajemen Universitas Muhammadiyah Sorong. Jurnal Sentralisasi, 8(1), 1-17.

Sumardi, K. (2007). Menakar jiwa wirausaha Mahasiswa Teknik Mesin Angkatan 2005. IV(10).

Suryana. (2006). Kewirausahaan. Jakarta,Salemba.

Ustha, E. (2018). Analisis faktor-faktor yang memotivasi mahasiswa berkeinginan menjadi wirausaha di Pekanbaru (Studi kasus pada empat universitas di Pekanbaru) Endrianto. Jurnal Tansiq, 1(2), 138-157. Retrieved from http://library1.nida.ac.th/termpaper6/s d/2554/19755.pdf

Wijaya, T. (2008). Kajian model empiris perilaku berwirausaha UKM DIY dan Jawa Tengah. Jurnal Manajemen Dan Kewirausahaan, 10(2), 93-104-104. https://doi.org/10.9744/jmk.10.2.pp.93104 
Pengaruh Dimensi Kepribadian - Farhanaz Safira \& Siti Zahreni 